\title{
Association between overweight and obesity with school performance in secondary students in Merida, Mexico
}

\author{
Juan C. Salazar-Rendón ${ }^{1,2 *}$, Nina Méndez ${ }^{3}$ and Hugo Azcorra ${ }^{4}$ \\ ${ }^{1}$ Departamento de Desarrollo Humano, Secretaría de Educación del Gobierno del Estado de Yucatán; ${ }^{2}$ Dirección de Nutrición, Servicios de Salud \\ de Yucatán; ${ }^{3}$ Universidad Marista de Mérida; ${ }^{4}$ Departamento de Ecología Humana, Centro de Investigación y de Estudios Avanzados del Instituto \\ Politécnico Nacional. Merida, Yucatan, Mexico
}

\begin{abstract}
Background: Some studies have found a negative relationship between obesity and school performance in scholars. However, this topic has not been studied in depth in Mexico. This study aimed to analyze the association between overweight and obesity with school performance in secondary school students in Merida. Methods: Weight and height were measured, and body mass index was calculated in a sample of 566 secondary students in Merida. Nutritional status was classified in normal weight (-2-<+1 standard deviation [SD]), overweight (+1-<2 SD) and obesity ( $>+2 S D)$ according to the World Health Organization criteria. The scores in language, mathematics, and sciences were used as indicators of school performance. Good performance was considered when the scores were $\geq 8$ points and poor performance when scores were $<8$ points. Logistic regression models were used to analyze the association between the variables. Results: The $44 \%$ of the sample met the criteria for overweight and obesity. After adjusting for school grade, type of school, number of absences, and Mayan surnames, we found that girls classified as obese had a significant risk of a poor performance in mathematics (odds ratio [OR]: 3.07; $95 \%$ confidence interval [Cl]: 1.39-6.80) and language (OR: 2.55; 95\% Cl: 1.14-5.71) compared with those with healthy weight. Conclusions: Our results suggest that obesity represents a risk of having a lower school performance in girls but not in boys.
\end{abstract}

Key words: School performance. Body mass index. Obesity. Adolescents.

\section{Asociación entre el sobrepeso y la obesidad con el rendimiento académico en estudiantes de secundaria de la ciudad de Mérida, México}

\section{Resumen}

Introducción: Diversos estudios señalan una relación negativa entre la obesidad y el rendimiento académico en la población infantil. Sin embargo, este tema ha sido poco estudiado en México. El objetivo de este estudio fue analizar la asociación entre el sobrepeso y la obesidad con el rendimiento académico en estudiantes de secundaria de Mérida. Métodos: Se midió el peso y la talla y se calculó el índice de masa corporal (IMC) en una muestra de 566 alumnos de ambos sexos de escuelas secundarias públicas de Mérida. Se clasificó el estado nutricional de los adolescentes en peso normal $(-2 /<+1$

\section{Correspondence:}

*Juan Carlos Salazar-Rendón

E-mail: juan.salazar@ssy.gob.mx
Available online: 10-08-2018 Bol Med Hosp Infant Mex. 2018;75:81-89

www.bmhim.com

2444-3409/@ 2018. Hospital Infantil de México Federico Gómez, published by Permanyer México SA de CV, all rights reserved. 
desviaciones estándar [DE]), sobrepeso $(+1 /<2 D E)$ y obesidad $(\geq+2 D E)$ de acuerdo con los valores de referencia de la Organización Mundial de la Salud (OMS). Se utilizó el promedio de calificaciones obtenidas en las asignaturas de lenguaje, matemáticas y ciencias como un indicador del rendimiento académico. Se consideró desempeño mayor cuando el promedio fue $\geq 8$ puntos y menor cuando fue $<8$ puntos. El análisis de asociación entre las variables se realizó mediante modelos de regresión logística. Resultados: La prevalencia conjunta de sobrepeso y obesidad fue del $44 \%$. Al ajustar para el grado escolar, el tipo de escuela, el número de ausencias y la procedencia maya del apellido, las adolescentes con obesidad tuvieron un riesgo significativo de tener desempeño menor en matemáticas (razón de momios [RM]: 3.07; IC 95\%: 1.39-6.80) y lenguaje (RM:2.55; IC 95\%:1.14-5.71) al compararlas con aquellas con peso saludable. Conclusiones: Los resultados sugieren que la obesidad es un factor de riesgo para tener un menor rendimiento académico en las adolescentes de entre 12 y 15 años, pero no entre los adolescentes de la misma edad.

Palabras clave: Rendimiento académico. IMC. Obesidad. Adolescentes.

\section{Introduction}

Obesity is currently a public health problem that affects people of all ages worldwide. During childhood and youth, obesity has been linked to a series of adverse events that increase the risk of cardiovascular, metabolic, joint and oncological diseases during adulthood ${ }^{1,2}$. Recent estimates suggest that younger generations could have shorter and less healthy lives compared to their parents as a result of the obesity epidemic ${ }^{3,4}$.

In Mexico, the overweight and obesity prevalence in children under 18 has increased considerably during the recent decades reaching the highest value worldwide $^{5}$. The National Survey of Health and Nutrition (ENSANUT, for its Spanish Acronym) of Midway 2016 indicates a combined overweight and obesity prevalence of $36.3 \%$ in Mexican adolescents between 12 and 19 years, with overweight predominating in female students $(26.4 \%$ vs. $18.5 \%)$ and obesity in males (15\% vs. $12.8 \%)^{6}$. In the Mexican state of Yucatán, the ENSANUT 2012 reported an overweight and obesity prevalence of $43.4 \%$ in adolescents, a figure that is above the national average, with a slightly higher prevalence in women than in men $(44.1 \% \text { vs. } 42.7 \%)^{7}$.

Scientific evidence indicates that overweight and obesity can affect, among other things, the academic performance of children and adolescents, which suggests that overweight and obesity could be associated not only with chronic diseases but also with the school-age population academic development and the human capital during adulthood $8-15$. In this regard, in a study with a longitudinal design carried out in Thailand, Mo-suwan et al. reported a negative association between academic performance and obesity in adolescence (grades 7-9), but not in childhood (grades 3-6) ${ }^{10}$. In the US, Datar and Sturm studied a group of students from the time they entered pre-school until they reached the third grade of primary school, and found that girls with obesity and those who during that period went from having a normal weight to suffer obesity were more likely to have a lower academic performance ${ }^{14}$. In both studies, obesity was determined when participants showed an exceeded BMI according to their age and sex.

Some authors have pointed out bad dietary and sleep habits, sedentary lifestyle and emotional problems as possible mechanisms of this phenomenon, as well as discrimination against people with obesity by their peers and teachers ${ }^{11,16-18}$. It has been proposed that the association between overweight and obesity with academic performance violate the individuals' quality of life because young people with obesity would be more likely to have fewer years of formal education and less chance of getting better-paid jobs ${ }^{19,20}$.

Although education spending has increased by more than $5 \%$ of gross domestic product in the recent years ${ }^{21}$, the Mexican educational system continues to face great challenges in its contribution to the human development of its population. The results obtained in tests to measure the country's educational progress have shown low levels of performance among Mexican students ${ }^{22,23}$. The Planea 2015 test showed a poor performance in language and communication and mathematics among third-year secondary students, in which only 6.1 and $3.1 \%$ of the participants obtained a satisfactory level, respectively ${ }^{22}$. For its part, the Organisation for Economic Co-operation and Development (OECD) has applied the Program for International Student Assessment (PISA) to assess the achievements and skills acquired by students at the end of compulsory education, where the results obtained by Mexican adolescents place the country among the most lagging members of the organization. The 2015 PISA test results place Mexico below the OECD average in science, reading, and mathematics, where less than $1 \%$ of 
Mexican students achieved excellence levels; when comparing results by gender, male students had better results in science and mathematics than female students, while female students outperformed male students in reading 23 .

The objective of this study was to analyze the association between overweight and obesity with academic performance in a sample of adolescents from 12 to 15 years of age who attend secondary school in the city of Mérida, Yucatán.

\section{Methods}

\section{Sample selection and description}

During May and June 2016, five public secondary schools in the city of Mérida were visited, randomly selected by stratum. Three of them belonged to the technical secondary schools' sub-system, which is differentiated, by including in their curriculum, subjects focused on the work environment at a technical level, and the rest belonged to the general secondary schools' subsystem. Groups within the schools also were randomly selected. The sample consisted of a total of 566 adolescents (293 females and 273 males) between 12 and 15 years of age.

\section{Anthropometric measurements}

Weight and height were obtained in the adolescents who participated in the study using a digital scale with a $100 \mathrm{~g}$ precision (Omron ${ }^{\circledR}$ HBF 514c) and a stadiometer with a $0.1 \mathrm{~cm}$ precision $\left(\mathrm{Seca}^{\circledR} 213\right)$, respectively. Trained personnel made the measurements following the standardized procedures suggested by Lohman et $\mathrm{a}^{24}$. In schools, participants were measured barefoot and in light clothing. Height and weight were used to calculate BMI $\left(\mathrm{BMI}=\right.$ weight $[\mathrm{kg}] /$ height $\left.^{2}\left[\mathrm{~m}^{2}\right]\right)$ of the participants, and the standardized values $(\mathrm{z})$ of this indicator were calculated using the WHO reference values of $2007^{25}$. The adolescents' nutritional status was classified into the following categories: normal weight $(-2-<+1 \mathrm{SD})$, overweight $(+1-<2 \mathrm{SD})$ and obesity $(>+2 \mathrm{SD})$.

\section{Academic performance measurement}

Basic education in Mexico is made up of the following levels: preschool, primary and secondary; the latter level lasts three years and is directed to a population between 12 and 16 years old. The official grading scale is numerical, from 5 to 10, with 6.0 being the minimum grade to pass. In the state of Yucatán, there are four subsystems of secondary education: general, state-run, technical and telesecundaria (distance-learning secondary school). For this study purposes, grades were used as an indicator of adolescents' academic performance; they were obtained from the school records and corresponded to the period of March-April of the 20152016 school year. The grades were classified into two categories: 1) good performance when they were at least 8 points; and 2) poor performance when they were less than 8 points. Although this cut-off point is arbitrary, the score 8 represents the intermediate point on the grading scale.

\section{Ethical considerations}

Authorization was obtained from the Secretaría de Educación del Estado de Yucatán (Ministry of Education of the State of Yucatan) to carry out the study in the selected schools. The researchers informed the directors of the schools, and the selected adolescents about the study objectives and asked for their consent to participate in the study. The informed consent of all the participants was obtained. For the maintenance of the adolescents' privacy, the anthropometric measurements were made in a space specifically destined for this activity assigned by the school's administration. The measurements were carried out solely in the presence of the research team.

\section{Statistical analysis}

The differences in the mean BMI values (absolute values and $z$ scores) between the categories of academic performance and sex were analyzed using unpaired Student's T-tests. The $\chi^{2}$ test was applied to examine the differences in the proportions of individuals belonging to each nutritional status group concerning the categories of academic performance. The analysis of the association between nutritional status and academic performance was carried out using logistic regression models. The response variable was the students' academic performance $(0=$ good performance, $1=$ poor performance). Regression models were adjusted to predict language, mathematics, and science performance. Different models were developed for both sexes. The independent variable of interest was the students' nutritional status expressed by the BMI $(0=$ normal weight, $1=$ overweight and $2=$ obesity). The analysis was restricted to these categories since only five individuals 
Table 1. General characteristics of the sample by sex

\begin{tabular}{|c|c|c|c|c|}
\hline \multirow[t]{2}{*}{ Variable } & All participants & Male & Female & \multirow[t]{2}{*}{ Difference } \\
\hline & Mean (SD) & Mean (SD) & Mean (SD) & \\
\hline$n$ & $566(100 \%)$ & $273(48 \%)$ & $293(52 \%)$ & - \\
\hline Age & $14.05( \pm 0.94)$ & $14.13( \pm 0.93)$ & $13.98( \pm 0.95)$ & $t=1.86, P=0.064$ \\
\hline $\begin{array}{l}\text { Type of schoo } \\
\text { General } \\
\text { Technical }\end{array}$ & $\begin{array}{l}249(44 \%) \\
317(56 \%)\end{array}$ & $\begin{array}{l}132(48 \%) \\
141(52 \%)\end{array}$ & $\begin{array}{l}117(40 \%) \\
176(60 \%)\end{array}$ & $X^{2}{ }_{(1)}=4.06, p=0.044$ \\
\hline $\begin{array}{l}\text { School grade } \\
\text { First } \\
\text { Second } \\
\text { Third }\end{array}$ & $\begin{array}{l}188(33 \%) \\
241(43 \%) \\
137(24 \%)\end{array}$ & $\begin{array}{c}86(32 \%) \\
118(43 \%) \\
69(25 \%)\end{array}$ & $\begin{array}{c}102(35 \%) \\
123(42 \%) \\
68(23 \%)\end{array}$ & $X^{2}{ }_{(2)}=0.76, p=0.681$ \\
\hline Absences & Median $=2$ & Median $=2$ & Median $=2$ & $z=-0.42, P=0.673$ \\
\hline $\begin{array}{l}\text { Surnames } \\
\text { Non-Mayan } \\
\text { Mayan }\end{array}$ & $\begin{array}{l}301(53 \%) \\
265(47 \%)\end{array}$ & $\begin{array}{l}142(52 \%) \\
131(48 \%)\end{array}$ & $\begin{array}{l}159(54 \%) \\
134(46 \%)\end{array}$ & $X^{2}{ }_{(1)}=0.29, p=0.592$ \\
\hline $\begin{array}{l}\text { Academic per } \\
\text { Language } \\
\text { Good } \\
\text { Poor }\end{array}$ & $\begin{array}{l}312(55 \%) \\
253(45 \%)\end{array}$ & $\begin{array}{l}123(45 \%) \\
150(55 \%)\end{array}$ & $\begin{array}{l}189(65 \%) \\
103(35 \%)\end{array}$ & $X^{2}{ }_{(1)}=22.08, p<0.001$ \\
\hline $\begin{array}{l}\text { Mathematics } \\
\text { Good } \\
\text { Poor }\end{array}$ & $\begin{array}{l}274(49 \%) \\
291(51 \%)\end{array}$ & $\begin{array}{l}122(45 \%) \\
151(55 \%)\end{array}$ & $\begin{array}{l}152(52 \%) \\
140(48 \%)\end{array}$ & $X^{2}{ }_{(1)}=3.06, p=0.080$ \\
\hline $\begin{array}{c}\text { Sciences } \\
\text { Good } \\
\text { Poor }\end{array}$ & $\begin{array}{l}359(64 \%) \\
206(36 \%)\end{array}$ & $\begin{array}{l}153(56 \%) \\
120(44 \%)\end{array}$ & $\begin{array}{l}206(71 \%) \\
86(29 \%)\end{array}$ & $X^{2}{ }_{(1)}=12.81, p<0.001$ \\
\hline
\end{tabular}

$S D$, standard deviation; $p$, level of significance; $X^{2}$, Chi-square test.

showed a low BMI (<-2 SD). All the models were adjusted for the students' school grade level $(1=$ first, 2 = second and $3=$ third), the number of absences in the studied school-period (continuous variable), the type of school $(0=$ general and $1=$ technical $)$ and the Mayan origin of the student's surname $(0=$ without Mayan surnames and $1=$ one or two Mayan surnames). The school type was used as an indicator of the students' socioeconomic conditions; in the local context, technical secondary schools receive students in more adverse socioeconomic conditions compared to the rest of the schools. Previous works indicate that students with Mayan ancestry tend to show a different academic performance from the rest of the population ${ }^{26}$. The category of normal BMI and the following socioeconomic categories were used as references in the models' specification: first grade of secondary school, general school and without Mayan surnames. All the analyses were performed at a significance level of $\alpha=0.05$ with the Stata ${ }^{\circledR}$ statistical package (StataCorp Lp 11.2).

\section{Results}

Table 1 describes the general characteristics of the studied sample. The mean age of the students was 14.05 years (SD: 0.94$)$ and the distribution according to their grade level was 33,43 and $24 \%$ in the first, second and third grades, respectively. $56 \%$ of the participants were recruited in technical schools, and $47 \%$ had at least one surname of Mayan origin. Higher proportions (with statistical significance) of women showed higher performance in language and science.

Females showed significantly higher BMl values than males (mean: $22.66 \mathrm{~kg} / \mathrm{m}^{2}$ [SD: 3.91] vs. mean: $21.99 \mathrm{~kg} / \mathrm{m}^{2}$ [SD: 3.92], $\mathrm{p}<0.05$ ) (Table 2). From the studied individuals, $44 \%$ were overweight or obese (overweight: $28 \%$, obese: $16 \%$ ), the figures were very similar between both sexes (males: $42 \%$, females: $44 \%$ ). Female students with lower academic performance in mathematics showed significantly higher BMI (absolute) values than those with higher academic performance. It was also observed that female students with lower academic 
Table 2. Descriptive statistics of the BMI and the proportion of individuals in the different nutritional status categories according to academic performance in language, mathematics, and science

\begin{tabular}{|c|c|c|c|c|c|c|c|}
\hline \multirow{3}{*}{ Indicator } & \multirow{3}{*}{$\begin{array}{c}\text { All participants } \\
\text { Mean (SD) }\end{array}$} & \multicolumn{2}{|c|}{ Language } & \multicolumn{2}{|c|}{ Mathematics } & \multicolumn{2}{|c|}{ Sciences } \\
\hline & & Good & Poor & Good & Poor & Good & Poor \\
\hline & & Mean (SD) & Mean (SD) & Mean (SD) & Mean (SD) & Mean (SD) & Mean (SD) \\
\hline \multicolumn{8}{|l|}{ Females } \\
\hline \multirow[t]{2}{*}{ BMI $\left(\mathrm{kg} / \mathrm{m}^{2}\right)$} & $22.66(3.91)$ & $22.38(3.86)$ & $23.23(3.96)$ & $22.17(3.46)$ & $23.24(4.27)$ & $22.45(3.87)$ & $23.24(3.95)$ \\
\hline & & \multicolumn{2}{|c|}{$t=-1.78, P=0.060$} & \multicolumn{2}{|c|}{$t=-2.36, P=0.019$} & \multicolumn{2}{|c|}{$t=-1.58, P=0.115$} \\
\hline \multirow[t]{2}{*}{ BMI-Z } & $0.58(0.79)$ & $0.77(1.03)$ & $0.95(0.99)$ & $0.72(0.93)$ & $0.95(1.10)$ & $0.78(1.02)$ & $0.96(1.01)$ \\
\hline & & \multicolumn{2}{|c|}{$\mathrm{t}=-1.47, \mathrm{P}=0.141$} & \multicolumn{2}{|c|}{$\mathrm{t}=-1.87, \mathrm{P}=0.061$} & \multicolumn{2}{|c|}{$t=-1.78, P=0.060$} \\
\hline \multirow[t]{2}{*}{$\begin{array}{l}\text { BMI } \\
\text { Normal } \\
\text { Overweight } \\
\text { Obesity }\end{array}$} & $\begin{array}{l}56 \%(164) \\
30 \%(87) \\
14 \%(41)\end{array}$ & $\begin{array}{l}58 \%(109) \\
31 \%(58) \\
11 \%(21)\end{array}$ & $\begin{array}{l}53 \%(54) \\
28 \%(29) \\
19 \%(20)\end{array}$ & $\begin{array}{c}59 \%(90) \\
32 \%(48) \\
9 \%(13)\end{array}$ & $\begin{array}{l}52 \%(73) \\
28 \%(39) \\
20 \%(28)\end{array}$ & $\begin{array}{l}58 \%(119) \\
28 \%(58) \\
14 \%(28)\end{array}$ & $\begin{array}{l}51 \%(44) \\
34 \%(29) \\
15 \%(13)\end{array}$ \\
\hline & & \multicolumn{2}{|c|}{$X^{2}=3.74, p=0.154$} & \multicolumn{2}{|c|}{$X^{2}=7.79, p=0.020$} & \multicolumn{2}{|c|}{$X^{2}=1.20, p=0.548$} \\
\hline \multicolumn{8}{|l|}{ Males } \\
\hline \multirow[t]{2}{*}{ BMI $\left(\mathrm{kg} / \mathrm{m}^{2}\right)$} & 21.99 (3.92) & $21.76(3.81)$ & $22.17(4.02)$ & $21.80(3.80)$ & $22.13(4.02)$ & $21.83(3.99)$ & $22.18(3.84)$ \\
\hline & & \multicolumn{2}{|c|}{$t=-0.86, P=0.391$} & \multicolumn{2}{|c|}{$\mathrm{t}=-0.69, \mathrm{P}=0.491$} & \multicolumn{2}{|c|}{$t=-0.73, P=0.466$} \\
\hline \multirow[t]{2}{*}{ BMI-Z } & $0.56(0.99)$ & $0.73(1.18)$ & $0.83(1.19)$ & $0.71(1.18)$ & $0.84(1.20)$ & $0.73(1.21)$ & $0.85(1.17)$ \\
\hline & & \multicolumn{2}{|c|}{$\mathrm{t}=-0.64, \mathrm{P}=0.520$} & \multicolumn{2}{|c|}{$\mathrm{t}=-0.89, \mathrm{P}=0.373$} & \multicolumn{2}{|c|}{$\mathrm{t}=-0.87, \mathrm{P}=0.385$} \\
\hline \multirow[t]{2}{*}{$\begin{array}{l}\text { BMI } \\
\text { Normal } \\
\text { Overweight } \\
\text { Obesity }\end{array}$} & $\begin{array}{c}57 \%(153) \\
26 \%(69) \\
16 \%(47)\end{array}$ & $\begin{array}{l}57 \%(68) \\
27 \%(33) \\
16 \%(19)\end{array}$ & $\begin{array}{l}57 \%(85) \\
24 \%(36) \\
19 \%(28)\end{array}$ & $\begin{array}{l}56 \%(66) \\
30 \%(36) \\
14 \%(17)\end{array}$ & $\begin{array}{l}58 \%(87) \\
22 \%(33) \\
20 \%(30)\end{array}$ & $\begin{array}{l}57 \%(86) \\
25 \%(37) \\
18 \%(27)\end{array}$ & $\begin{array}{l}56 \%(67) \\
27 \%(32) \\
17 \%(20)\end{array}$ \\
\hline & & \multicolumn{2}{|c|}{$X^{2}=0.62, p=0.732$} & \multicolumn{2}{|c|}{$X^{2}=3.08, p=0.215$} & \multicolumn{2}{|c|}{$X^{2}=0.19, p=0.907$} \\
\hline
\end{tabular}

SD, standard deviation; $p$, level of significance; t, Student's t-test; BMI, body mass index; BMI-Z, BMI Z-score normal weight (-2 - <+1 SD), overweight (+1 - < 2 SD) and obesity (> +2 SD).

performance in this area showed a significantly higher proportion of overweight and obesity compared to those with high academic performance. This result was not found in males for any analyzed knowledge area.

The results of the logistic regression models for each knowledge area are shown in tables 3 to 5 . We found that the obesity category was significantly associated to a higher risk of poor academic performance in language (OR: $2.55,95 \%$ confidence interval [Cl]: 1.14-5.71) and mathematics (OR: $3.07,95 \% \mathrm{Cl}: 1.39-6.80)$, this result was significant in women but not in men. The number of absences in the studied school-period increased the probabilities of poor performance in all academic areas for men and women. Moreover, the models suggested that young people both females and males were more likely to have poor performance in the language area in technical secondary schools. None of the interactions between the independent variables was significant.

\section{Discussion}

The overweight and obesity prevalence found in this research $(44 \%)$ is comparable to the reported in the ENSANUT $2012^{7}$ (43.4\%) among young people between 12 and 19 years old living in Yucatán, also with the one obtained by the National School Health Survey (ENSE, for its Spanish acronym) in $2008^{27}(41 \%)$ in Yucatán high school students between 12 and 16 years of age. These similarities give reliability to our results and confirm that overweight and obesity continue to be an alarming public health problem among adolescents living in Yucatán.

Different studies that address the association between obesity and academic performance show discrepant results; some studies have found a positive association, while others have not seen a relationship ${ }^{8-15,28-32}$. These discrepancies could be due to differences in age 
Table 3. Logistic regression model of biosocial factors for poor academic performance in language

\begin{tabular}{|c|c|c|c|c|c|c|c|c|}
\hline & $\mathbf{n}$ & & & p value & $\mathbf{n}$ & & & p value \\
\hline & & $\begin{array}{c}\text { OR }(95 \% \text { CI) } \\
\text { raw }\end{array}$ & $\begin{array}{l}\text { OR (95\% CI) } \\
\text { adjusted }\end{array}$ & & & OR $(95 \%$ CI) raw & $\begin{array}{l}\text { OR (95\% CI) } \\
\text { adjusted }\end{array}$ & \\
\hline $\begin{array}{l}\text { BMI } \\
\text { Normal } \\
\text { Overweight } \\
\text { Obesity }\end{array}$ & $\begin{array}{l}164 \\
87 \\
41\end{array}$ & $\begin{array}{c}1 \\
1.01(0.58-1.75) \\
1.92(0.96-3.85)\end{array}$ & $\begin{array}{c}1 \\
1.19(0.63-2.26) \\
2.55(1.14-5.71)\end{array}$ & $\begin{array}{c}- \\
0.588 \\
0.023\end{array}$ & $\begin{array}{l}153 \\
69 \\
47\end{array}$ & $\begin{array}{c}1 \\
0.87(0.49-1.54) \\
1.18(0.61-2.29)\end{array}$ & $\begin{array}{c}1 \\
0.83(0.44-1.54) \\
1.13(0.54-2.36)\end{array}$ & $\begin{array}{c}- \\
0.547 \\
0.738\end{array}$ \\
\hline $\begin{array}{l}\text { School grade } \\
\text { level } \\
1^{\text {st }} \text { grade } \\
2^{\text {nd }} \text { grade } \\
3^{\text {rd }} \text { grade }\end{array}$ & $\begin{array}{c}101 \\
123 \\
68\end{array}$ & $\begin{array}{c}1 \\
2.10(1.18-3.72) \\
1.81(0.93-3.51)\end{array}$ & $\begin{array}{c}1 \\
2.13(1.10-4.14) \\
1.11(0.52-2.37)\end{array}$ & $\begin{array}{c}- \\
0.025 \\
0.794\end{array}$ & $\begin{array}{c}85 \\
115 \\
69\end{array}$ & $\begin{array}{c}1 \\
0.85(0.48-1.48) \\
1.16(0.61-2.20)\end{array}$ & $\begin{array}{c}1 \\
1.07(0.58-2.00) \\
0.76(0.37-1.58)\end{array}$ & $\begin{array}{c}- \\
0.823 \\
0.465\end{array}$ \\
\hline Absences & 292 & $1.24(1.16-1.33)$ & $1.26(1.17-1.36)$ & $<0.001$ & 269 & $1.19(1.10-1.29)$ & $1.21(1.12-1.32)$ & $<0.001$ \\
\hline $\begin{array}{l}\text { Type of school } \\
\text { General } \\
\text { Technical }\end{array}$ & $\begin{array}{l}116 \\
176\end{array}$ & $\begin{array}{c}1 \\
2.75(1.62-4.66)\end{array}$ & $\begin{array}{c}1 \\
3.03(1.64-5.62)\end{array}$ & $<-\overline{0} .001$ & $\begin{array}{l}129 \\
140\end{array}$ & $\begin{array}{c}1 \\
2.12(1.30-3.44)\end{array}$ & $\begin{array}{c}1 \\
2.19(1.28-3.76)\end{array}$ & 0.004 \\
\hline $\begin{array}{l}\text { Surnames } \\
\text { Non-Mayan } \\
\text { Mayan }\end{array}$ & $\begin{array}{l}158 \\
134\end{array}$ & $\begin{array}{c}1 \\
1.05(0.65-1.69)\end{array}$ & $\begin{array}{c}1 \\
0.93(0.52-1.66)\end{array}$ & $\begin{array}{c}- \\
0.808\end{array}$ & $\begin{array}{l}138 \\
131\end{array}$ & $\begin{array}{c}1 \\
1.52(0.94-2.46)\end{array}$ & $\begin{array}{c}1 \\
1.58(0.93-2.67)\end{array}$ & $\begin{array}{c}- \\
0.089\end{array}$ \\
\hline
\end{tabular}

$\mathrm{OR}$, odds ratio; $\mathrm{SD}$, standard deviation; $\mathrm{p}$, level of significance; $\mathrm{Cl}$, confidence interval

Normal weight $(-2-<+1 \mathrm{SD})$, Overweight $(+1-<2 \mathrm{SD})$, Obesity $(>+2 \mathrm{SD})$.

The model was adjusted for the following variables: school grade level, number of absences in the studied school-period, type of school and student's Mayan ancestry according to the presence of Mayan surnames.

Table 4. Logistic regression model of biosocial factors for poor academic performance in mathematics

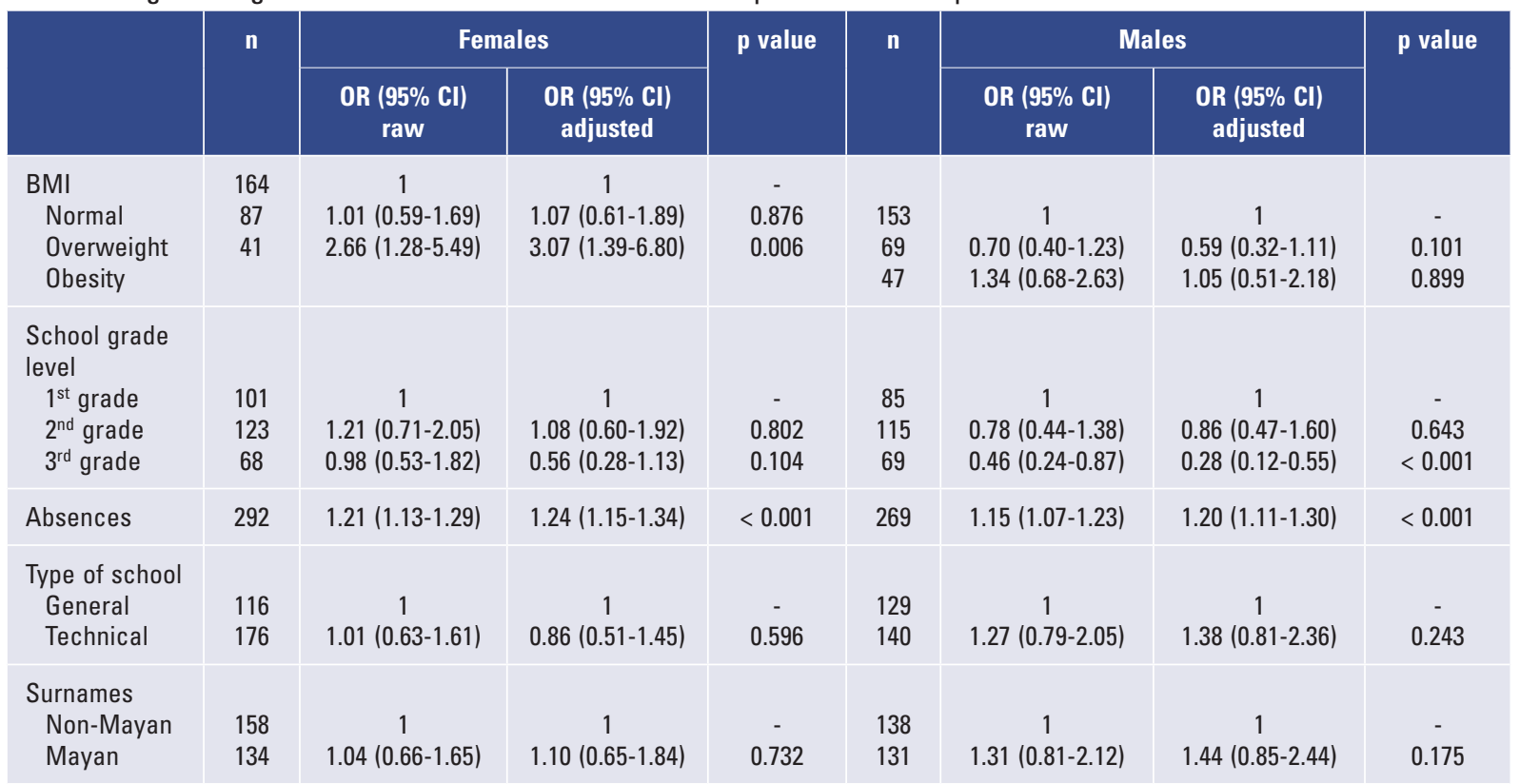

$\mathrm{OR}$, odds ratio; $\mathrm{SD}$, standard deviation; $\mathrm{p}$, level of significance; $\mathrm{Cl}$, confidence interval Normal weight $(-2-<+1 \mathrm{SD})$, Overweight $(+1-<2 \mathrm{SD})$, Obesity $(>+2 \mathrm{SD})$.

The model was adjusted for the following variables: school grade level, number of absences in the studied school-period, type of school and student's Mayan ancestry according to the presence of Mayan surnames.

groups and socioeconomic characteristics among the studied populations, as well as the different methods used to assess academic performance in children and young people. 
Table 5. Logistic regression model of biosocial factors for poor academic performance in sciences

\begin{tabular}{|c|c|c|c|c|c|c|c|c|}
\hline & \multirow[t]{2}{*}{$\mathbf{n}$} & \multicolumn{2}{|c|}{ Females } & \multirow[t]{2}{*}{$\mathrm{p}$ value } & \multirow[t]{2}{*}{ n } & \multicolumn{2}{|c|}{ Males } & \multirow[t]{2}{*}{ p value } \\
\hline & & OR $(95 \%$ CI) raw & $\begin{array}{l}\text { OR (95\% CI) } \\
\text { adjusted }\end{array}$ & & & $\begin{array}{c}\text { OR }(95 \% \text { CI) } \\
\text { raw }\end{array}$ & $\begin{array}{l}\text { OR (95\% CI) } \\
\text { adjusted }\end{array}$ & \\
\hline $\begin{array}{l}\text { BMI } \\
\quad \text { Normal } \\
\text { Overweight } \\
\text { Obesity }\end{array}$ & $\begin{array}{c}164 \\
87 \\
41\end{array}$ & $\begin{array}{c}1 \\
1.35(0.77-2.38) \\
1.26(0.60-2.64)\end{array}$ & $\begin{array}{c}1 \\
1.46(0.80-2.67) \\
1.22(0.54-2.73)\end{array}$ & $\begin{array}{c}- \\
0.222 \\
0.630\end{array}$ & $\begin{array}{l}153 \\
69 \\
47\end{array}$ & $\begin{array}{c}1 \\
1.11(0.63-1.96) \\
0.95(0.49-1.84)\end{array}$ & $\begin{array}{c}1 \\
1.25(0.66-2.37) \\
1.07(0.51-2.23)\end{array}$ & $\begin{array}{c}- \\
0.488 \\
0.859\end{array}$ \\
\hline $\begin{array}{l}\text { School grade } \\
\text { level } \\
1^{\text {st }} \text { grade } \\
2^{\text {nd }} \text { grade } \\
3^{\text {rd }} \text { grade }\end{array}$ & $\begin{array}{l}101 \\
123 \\
68\end{array}$ & $\begin{array}{c}1 \\
1.36(0.75-2.48) \\
2.01(1.03-3.93)\end{array}$ & $\begin{array}{c}1 \\
1.13(0.59-2.14) \\
1.59(0.78-3.23)\end{array}$ & $\begin{array}{c}- \\
0.718 \\
0.202\end{array}$ & $\begin{array}{c}85 \\
115 \\
69\end{array}$ & $\begin{array}{c}1 \\
1.86(1.06-3.29) \\
1.02(0.53-1.96)\end{array}$ & $\begin{array}{c}1 \\
2.01(1.07-3.79) \\
0.64(0.29-1.39)\end{array}$ & $\begin{array}{c}- \\
0.030 \\
0.256\end{array}$ \\
\hline Absences & 292 & $1.14(1.08-1.20)$ & $1.14(1.08-1.20)$ & $<0.001$ & 269 & $1.18(1.10-1.26)$ & $1.24(1.15-1.34)$ & $<0.001$ \\
\hline $\begin{array}{l}\text { Type of } \\
\text { school } \\
\text { General } \\
\text { Technical }\end{array}$ & $\begin{array}{l}116 \\
176\end{array}$ & $\begin{array}{c}1 \\
0.84(0.50-1.40)\end{array}$ & $\begin{array}{c}1 \\
0.77(0.44-1.35)\end{array}$ & $\begin{array}{c}- \\
0.364\end{array}$ & $\begin{array}{l}129 \\
140\end{array}$ & $\begin{array}{c}1 \\
0.46(0.28-0.74)\end{array}$ & $\begin{array}{c}1 \\
0.44(0.25-0.77)\end{array}$ & 0.004 \\
\hline $\begin{array}{l}\text { Surnames } \\
\text { Non-Mayan } \\
\text { Mayan }\end{array}$ & $\begin{array}{l}158 \\
134\end{array}$ & $\begin{array}{c}1 \\
0.56(0.34-0.95)\end{array}$ & $\begin{array}{c}1 \\
0.59(0.34-1.03)\end{array}$ & 0.064 & $\begin{array}{l}138 \\
131\end{array}$ & $\begin{array}{c}1 \\
0.86(0.53-1.38)\end{array}$ & $\begin{array}{c}1 \\
0.94(0.55-1.61)\end{array}$ & $\overline{-}-$ \\
\hline
\end{tabular}

$\mathrm{OR}$, odds ratio; $\mathrm{SD}$, standard deviation; $\mathrm{p}$, level of significance; $\mathrm{Cl}$, confidence interval

Normal weight $(-2-<+1 \mathrm{SD})$, Overweight $(+1-<2 \mathrm{SD})$, Obesity $(>+2 \mathrm{SD})$.

The model was adjusted for the following variables: school grade level, number of absences in the studied school-period, type of school and student's Mayan ancestry according to the presence of Mayan surnames.

In the current study, it was found that women with a higher BMI showed an increased risk of having poor academic performance. Our findings coincide with those reported by Sabia ${ }^{13}$, who found a negative relationship between BMI and the grades obtained by white women between 14 and 17 years old in the US. However, this association lost its significance in non-white women and males of the same age range. Our results also coincide with those reported by Datar and Sturm, who followed American children during their early years in primary education and found that excessive weight gain during the first years of primary school was a significant risk factor for obtaining adverse results in academic performance among girls, but not in boys ${ }^{14}$.

Our results show that young women with obesity criteria have a higher risk of having a poor performance in language and mathematics specifically. Similar results have been found by Judge and Jahns ${ }^{9}$, Mo-suwan et al. ${ }^{10}$ and Datar et al. ${ }^{15}$ who reported in different studies a significant association between obesity and lower academic performance in mathematics and language in pre-school, school-age and adolescent children, regardless of sex. However, Judge and Jahns ${ }^{9}$ found that the association is attenuated after controlling the influence of socioeconomic variables and maternal education. Another study conducted on children in primary education in Canada found that participants who had presented obesity during preschool and had achieved later a healthy weight in primary school were able to improve their grades in mathematics ${ }^{32}$. Unlike our findings, these studies do not report whether their results varied according to the sex of the participants.

The possible mechanisms that explain the relationship between overweight and obesity with academic performance are not yet clear. The literature shows an association between cognitive function and adiposity, in which functions of cognitive control, visuospatial skills, and mental ability are altered in children with excessive adiposity ${ }^{33,34}$. In this sense, Portillo-Reyes et al. analyzed the neuropsychological performance and nutritional status of a sample of Mexican children between 8 and 12 years old from the low socioeconomic level that belonged to urban environments. The results showed that children with obesity had a lower performance than children with healthy weight in tasks related to memory, abstract reasoning, and in following instructions ${ }^{35}$.

Health habits such as diet, physical activity, and sleep, as well as psychosocial factors, have been proposed as links between overweight and obesity with poor academic performance during childhood and youth $^{11}$. Studies conducted in Canada and Korea have 
found that the habit of eating breakfast and a healthy diet are factors associated with higher academic performance in children and adolescents ${ }^{36-38}$. In particular, Kang and Park reported that adolescents who did not eat breakfast had lower grades in language, mathematics, and foreign language compared with those who did eat it ${ }^{38}$. Haapala et al. reported that certain diets, such as the Mediterranean or the Baltic, were associated with better reading skills, but not with better arithmetic skills among Finnish children who were in the first years of primary school ${ }^{39}$.

Regarding sleep habits, a study conducted in Mexico analyzed the academic performance of a group of adolescent girls between 15 and 18 years of age, finding that those participants who covered the obesity criteria and who also had daytime hypersomnia had a $0.7 \%$ lower academic performance than their peers with a healthy weight and without sleep disorders ${ }^{16}$.

The physical activity benefits seem to extend to academic performance, as suggested by Kantomaa et al., who found that physically active adolescents were twice as likely to have better grades compared to sedentary adolescents ${ }^{40}$. For their behalf, Carlson et al. ${ }^{41}$ reported that in North American girls attending primary school, greater physical activity time (70-300 min/week) was associated with academic improvement in mathematics and reading. Another study conducted in the US, with students in the third and fifth grades in public schools, reported that aerobic fitness was positively associated with general academic performance, and in mathematics and reading areas ${ }^{42}$. Endorphins release could regulate these benefits because they improve the mood also could be provided by the socialization that implies the practice of a sport.

Some evidence supports the role of psychosocial factors in academic performance. It has been reported that children who have obesity suffer from more mockery and bullying than their peers; this harassment could decrease their self-esteem and consequently affect their academic performance ${ }^{43-45}$. It is possible that the overweight and obesity influence on academic performance is largely manifested in women. This influence seems to have consequences that affect women's education, employment, healthcare and interpersonal relationships ${ }^{46,47}$. Crosnoe found that obese girls were less likely to attend university after finishing high school compared to their peers with a healthy weight; this difference was not observed among men with overweight and obesity ${ }^{48}$.

The present study has some limitations that should be discussed. On the one hand, because it is a cross-sectional study, it is not intended to indicate that obesity has a causal effect on academic performance, but that both factors are associated. On the other hand, the analyzed school grades belong to only one two-month period of the school year, so they do not represent the students' overall performance. Moreover, the teaching staff of the schools assigned the grades, so the possibility of some inherent bias in the teachers' criteria and their evaluation cannot be rejected.

In summary, the present results showed that girls with obesity had an increased risk of having poor academic performance in language and mathematics. These results were not observed in males in any analyzed area. In the future, it is necessary to study the role of other factors, such as socioeconomic level, diet, and physical activity, in the academic performance of the school-age population with the aim of implementing policies directed to improve their health conditions and increase their possibilities of human development.

\section{Ethical responsibilities}

Protection of humans and animals. The authors declare that no experiments have been conducted on humans or animals for this research.

Data confidentiality. The authors declare that they have followed the protocols of their work center on the publication of patients' data.

Right to privacy and informed consent. The authors have obtained the informed consent of the patients and subjects referred to in the article. These documents are in possession of the corresponding author.

\section{Conflicts of interest}

The authors declare no conflicts of interest.

\section{Acknowledgments}

The authors express their gratitude to the schools' administrative staff that participated in this study for all the support granted to carry out this work. Thanks are also given to all the participating students for their voluntary support. Equally, we express our gratitude to Nutritionist María José Peraza Ávila of the Departamento de Desarrollo Humano of the SEGEY and Ligia Martín, María Fernanda Rivero and Arantxa Ibarra, students of the Nutrition Degree from the Universidad Modelo, for their valuable collaboration during fieldwork. 


\section{References}

1. Daniels SR. The consequences of childhood overweight and obesity. Future Child. 2006;16:47-67.

2. Biro FM, Wien M. Childhood obesity and adult morbidities. Am J Clin Nutr. 2010;91:1499S-505S.

3. Fontaine KR, Redden DT, Wang C, Westfall AO, Allison DB. Years of life lost due to obesity. JAMA. 2003;289:187-93.

4. Olshansky SJ, Passaro DJ, Hershow RC, Layden J, Carnes BA, Brody J, et al. A potential decline in life expectancy in the United States in the $21^{\text {st }}$ century. N Eng J Med. 2005;352:1138-45.

5. Bonvecchio A, Safdie M, Monterrubio EA, Gust T, Villalpando S, Rivera JA. Overweight and obesity trends in Mexican children 2 to 18 years of age from 1988 to 2006. Salud Publica Mex. 2009;51:S586-94.

6. Instituto Nacional de Salud Pública. Encuesta Nacional de Salud y Nutrición de Medio Camino 2016. Cuernavaca, México: Instituto Nacional de Salud Pública; 2016.

7. Instituto Nacional de Salud Pública. Encuesta Nacional de Salud y Nutrición 2012. Resultados por entidad federativa, Yucatán [Internet]. Cuernavaca, México: Instituto Nacional de Salud Pública; 2013. Available at: encuestas.insp.mx.

8. Taras H, Potts-Datema. Obesity and student performance at school. J Sch Health. 2005;75:291-5.

9. Judge $S$, Jahns L. Association of overweight with academic performance and social and behavioral problems: an update from the early childhood longitudinal study. J Sch Health. 2007;77:672-8.

10. Mo-suwan L, Lebel L, Puetpaiboon A, Junjana C. School performance and weight status of children and young adolescents in a transitional society in Thailand. Int J of Obes. 1999;23:272-7.

11. Sigfúsdóttir ID, Kristjánsson AL, Allegrante JP. Health behavior and academic achievement in Icelandic school children. Health Educ Res. 2007:22:70-80.

12. Shore SM, Sachs ML, Lidicker JR, Brett SN, Wright AR, Libonati JR. Decreased scholastic achievement in overweight middle school students. Obesity. 2008;16:1535-8.

13. Sabia JJ. The effect of body weight on adolescent academic performance. South Econ J. 2007;73:871-900.

14. Datar A, Sturm R. Childhood overweight and elementary school outcomes. Int J Obes. 2006;30:1449-60.

15. Datar A, Sturm R, Magnabosco JL. Childhood overweight and academic performance: a national study of kindergartens and first-graders. Obes Res. 2004;12:58-68.

16. Lombardo-Aburto E, Velázquez-Moctezuma J, Flores-Rojas G, Casillas-Vaillard GA, Galvan-López A, García-Valdéz P, et al. Relación entre trastornos del sueño, rendimiento académico y obesidad en estudiantes de preparatoria. Acta Pediatr Mex. 2011;32:163-8.

17. Sikorski C, Luppa M, Brähler E, König HH, Riedel-Heller SG. Obese children, adults and senior citizens in the eyes of the general public: results of a representative on stigma and causation of obesity. PLoS One. 2012;7:e46924.

18. MacCann C, Roberts RD. Just smart but not as successful: obese students obtain lower school grades but equivalent test scores to non-obese students. Int J Obes. 2013;37:40-6.

19. Gortmarker SL, Must A, Perrin JM, Sobol AM, Dietz WH. Social and economic consequences of overweight in adolescence and young adulthood. N Engl J Med. 1993;329:1008-12.

20. Cawley J. The impact of obesity on wages. J Hum Resour. 2004;39:451-74

21. Organización para la Cooperación y el Desarrollo Económico [Internet]. México: Panorama de la educación [Fecha consulta:6 ene 2017]. Available at: http://www.oecd.org/mexico/Mexico-EAG2014-Country-Note-spanish.pdfhttp://www.oecd.org/mexico/Mexico-EAG2014-Country-Note-spanish.pdf.

22. Instituto Nacional para la Evaluación de la Educación (INEE) [Internet]. Plan Nacional para la Evaluación de los aprendizajes (Planea). Resultados nacionales 2015 [Fecha consulta:6 ene 2017]. Available at: http:// www.inee.edu.mx/images/stories/2015/planea/final/fasciculos-finales/resultadosPlanea-3011.pdf.

23. Organización para la Cooperación y el Desarrollo Económico [Internet]. Programa para la evaluación internacional de alumnos (PISA) PISA 2015 -resultados México. Available at: https://www.oecd.org/pisa/PISA-2015Mexico-ESP.pdf.
24. Lohman T, Roche A, Martorell R. Anthropometric standardization reference manual. Champaing: Human Kinetics Books;1991.

25. Onis MD, Onyango AW, Borghi E, Siyam A, Nishida C, Siekmann J. Development of WHO growth reference for school-aged children and adolescents. Bull World Health Organ. 2007;85:660-7.

26. Mendez N, Vera-Avilez M, Gonzalez-Herrera L, Dickinson F, Palma-Solis M, Prelip M. School grades and standardized test scores of children with and without obesity in south-east Mexico. Int $\mathrm{J}$ School Health. 2017;4:e36356.

27. Shama-Levy T, editor. Encuesta Nacional de Salud en Escolares 2008. Cuernavaca: Instituto Nacional de Salud Pública (MX); 2010.

28. Kaestner R, Grossman M. Effects of weight on children's educational achievement. Econ Educ Rev. 2009;28:651-61.

29. Barrigas C, Fragoso I. Obesity, academic performance and reasoning ability in Portuguese students between 6 and 12 years old. J Biosoc Sci. 2012;44:165-79.

30. Flores-Saldaña B, Guízar-Mendoza JM. Obesidad infantil y aprovechamiento escolar: ¿existe relación entre obesidad y aprovechamiento escolar? Rev Hosp Jua Mex. 2009;76:137-43.

31. Abdelalim A, Ajaj N, Al-Tmimy A, Alyousefi M, Al-Rashaidan S, Hammoud M, et al. Childhood obesity and academic achievement among male students in public primary schools in Kuwait. Med Princ Pract. 2012;21:14-9.

32. Carter MA, Dubois L, Ramsay T. Examining the relationship between obesity and math performance among Canadian school children: a prospective analysis. Int J Pediatr Obes. 2010;5:412-9.

33. Li Y, Dai Q, Jackson JC, Zhang J. Overweight is associated with decreased cognitive functioning among school-age children and adolescents. Obesity. 2008;16:1809-15.

34. Kamijo K, Khan NA, Pontifex MB, Scudder MR, Drollette ES, Raine LB, et al. The relationship of adiposity to cognitive control and scholastic achievement in preadolescent children. Obesity. 2012;20:2406-11.

35. Portillo-Reyes V, Puente AE, Pérez-García M, Loya-Méndez Y. Deterioro neuropsicológico en niños mexicanos con estados nutricionales alterados: desnutrición leve a moderada vs. obesidad. Rev Neuropsicología, Neuropsiquiatría y Neurociencias. 2011;11:133-46.

36. Florence MD, Asbridge M, Veugelers PJ. Diet quality and academic performance. J Sch Health. 2008;78:209-15.

37. Kim HYP, Frongillo EA, Han SS, Oh SY, Kim WK, Jang YA, et al. Academic performance of Korean children is associated with dietary behaviours and physical status. Asia Pacific J Clin Nutr. 2003;12:186-92.

38. Kang YW, Park JH. Does skipping breakfast and being overweight influence academic achievement among Korean adolescents? Osong Public Health Res Perspect. 2016;7:220-7.

39. Haapala EA, Eloranta AM, Venäläinen T, Jalkanen H, Poikkeus AM, Ahonen $T$, et al. Diet quality and academic achievement: a prospective study among primary school children. Eur J Nutr. 2017;56:2299-308.

40. Kantomaa MT, Stamatakis E, KankaanpääA, Kajantie E, Taanila A, Tammelin T. Association of physical activity and sedentary behavior with adolescent academic achievement. J Res Adolesc. 2015;26:432-42.

41. Carlson SA, Fulton JE, Lee SM, Maynard M, Brown DR, Kohl HW, et al. Physical education and academic achievement in elementary school: data from the Early Childhood Longitudinal Study. Am J Public Health. 2008;98:721-7.

42. Castelli DM, Hillman $\mathrm{CH}$, Buck SM, Erwin HE. Physical fitness and academic achievement in third- and fifth-grade students. J Sport Excer Psychol. 2007;29:239-52.

43. Krukowski RA, Smith West D, Philyaw Perez A, Bursac Z, Philips MM, Raczynski JM. Overweight children, weight-based teasing and academic performance. Int J Pediatr Obes. 2009;4:274-80.

44. Puhl RM, King KM. Weight discrimination and bullying. Best Pract Res Clin Endocrinol Metab. 2013;27:117-27.

45. Martin-Nemeth PA, Penckofer S. Psychological vulnerability among overweight/obese minority adolescents. J Sch Nurs. 2012;28:291-301.

46. Fikkan JL, Rothblum ED. Is fat a feminist issue? Exploring the gendered nature of weight bias. Sex Roles. 2012;66:575-92.

47. Chrisler JC. "Why can't you control yourself?" Fat should be a feminist issue. Sex Roles. 2012;66:608-16.

48. Crosnoe R. Gender, obesity and education. Sociol Educ. 2007;80:241-60. 